\title{
Projeção Mundial da Anestesiologia Brasileira
}

A World Federation of Societies of Anaesthesiologists WFSA) foi fundada oficialmente em 9 de Setembro de 1955, em histórica Assembléia realizada em Scheveningen, Holanda, durante o $1^{\circ}$ Congresso Mundial de Anestesiologistas, na qual tomaram parte 26 Sociedades Nacionais de Anestesiologia, entre elas a Sociedade Brasileira de Anestesiologia (SBA).

Hoje, passado quase meio século, a WFSA conta com 108 Sociedades-membro e 96403 médicos anestesiologistas em todo mundo ${ }^{1}$, todos envolvidos direta ou indiretamente na tarefa de fazer cumprir o principal objetivo da WFSA, que é tornar disponíveis a todos os povos os mais altos padrões de anestesia $^{2}$.

Ao longo destes quase cinqüenta anos, a SBA sempre teve papel destacado na direção e nas atividades da WFSA. Dr. Zairo Vieira, então Presidente da SBA, fez parte do primeiro Comitê Executivo da WFSA, constituído em Scheveningen. Em 1964, a SBA organizou o $3^{\circ}$ Congresso Mundial de Anestesiologistas, realizado em São Paulo, e naquela ocasião o Dr Luiz Fernando Rodrigues Alves foi eleito membro do Comitê Executivo da WFSA. Outros anestesiologistas do quadro da SBA foram eleitos para este cargo em diferentes ocasiões: Dr. Carlos Pereira Parsloe em 1972, Dr. José Carlos Ferraro Maia em 1980, Dr. José Roberto Nociti em 1996. Em 1984 , por ocasião do $7^{\circ}$ Congresso Mundial de Anestesiologistas em Manila, Filipinas, o Dr. Carlos Pereira Parsloe assumiu a Presidência da WFSA, cargo que honrou até 1988.

Atualmente a SBA, com 7319 sócios, é a terceira maior Sociedade-membro da WFSA, tendo à sua frente apenas as Sociedades Nacionais dos EUAe do Japão, com respectivamente 23727 e 8568 sócios ${ }^{1}$. Uma das funções da WFSA tem sido buscar o ponto de equilíbrio entre a atuação de Sociedades de grande porte e bem estruturadas como a SBA, e a de Sociedades minúsculas no outro extremo, como as de Zâmbia, Estônia e Cazaquistão com 15 sócios e a de Papua Nova Guiné com 10 sócios.

Muito se discute hoje sobre índices de excelência em Anestesiologia, como a proporção entre o número de médicos anestesiologistas e o número de pessoas de uma população por eles atendidas. Vários fatores são determinantes deste índice, entre os quais o tamanho da população, o seu estágio de desenvolvimento econômico, o número de médicos que se formam anualmente, a ocorrência de paramédicos que praticam a anestesia. A SBA sempre defendeu, através de seus representantes na WFSA, a idéia de que a anestesia é um ato médico e, como tal, deve ser praticada por médicos com as atribuições necessárias à sua realização com qualidade e segurança. Tendo em vista o alto padrão da Anestesiologia norte-americana, o índice de 1 anestesiologista para 11.700 habitantes, é considerado por muitos como padrão ideal de referência ${ }^{3}$. Também sob este aspecto a Anestesiologia brasileira se destaca, figurando entre países que exibem índices entre o ideal referido e 1:25.000, ao lado de Japão, Reino Unido, Itália, França, Espanha, Argentina, Uruguai ${ }^{4}$. No outro extremo, situam-se países como Nepal (1:287.000), Vietnã (1:197.000), Tailândia (1:124.000) e, Guatemala (1:246.000), Equador $(1: 156.000)$ e Haiti $(1: 151.000)^{3,4}$.

A projeção da Anestesiologia brasileira no mundo tem sido patente. A Revista Brasileira de Anestesiologia é uma das poucas publicações bilíngües, podendo ser lida hoje pelos médicos de países de língua inglesa ou que adotam o inglês como sua segunda língua. Além disso, sua indexação na SciELO (Scientific Electronic Library On Line) e na EMBASE (Excerpta Medica Database) estimula colegas estrangeiros a visitarem a produção científica nacional. A organização, a qualidade e o número de participantes dos Congressos Brasileiros de Anestesiologia foram apreciados recentemente por dois membros do alto escalão administrativo da WFSA que aqui compareceram: TC Kester Brown, Presidente $\left(47^{\circ}\right.$ CBA, São Paulo, 2000) e Anneke Meursing, Secretária Geral (50 CBA, Brasília, 2003). O $13^{\circ}$ Congresso Mundial de Anestesiologistas, Paris 2004, teve 16 membros da SBA entre os convidados oficiais para participarem de conferências e mesas redondas, número nunca antes atingido em Congressos Mundiais realizados fora do Brasil. E finalmente os autores brasileiros têm visto seus trabalhos científicos aceitos para publicação em diversas revistas da especialidade no exterior, tanto européias como norte-americanas.

Às novas gerações impõe-se o desafio de não só manter como ampliar esta projeção internacional da Anestesiologia brasileira, comparecendo a Congressos, publicando artigos, participando de atividades associativas e ocupando os espaços que são legitimamente nossos pela qualidade e seriedade do nosso trabalho.

José Roberto Nociti, TSA

Membro do Comitê Executivo daWFSA Membro do Conselho Editorial da RBA

Rua Stélio Machado Loureiro, 21

14025-470 Ribeirão Preto - SP

\section{International Projection of Brazilian Anesthesiology}

The World Federation of Societies of Anaesthesiologists (WFSA) was officially founded in September 9, 1955, in historical Assembly held in Scheveningen, The Netherlands, 
during the $1^{\text {st }}$ World Congress of Anesthesiologists, attended by 26 National Anesthesiology Societies, among which the Brazilian Society of Anesthesiology (SBA).

Today, almost half century after, WFSA counts on 108 member-Societies and 96403 anesthesiologists worldwide ${ }^{1}$, all directly or indirectly involved with meeting major WFSA objective, which is to make the highest anesthetic standards available to all peoples ${ }^{2}$.

Along these almost fifty years, SBA has always had a prominent role in WFSA Board and activities. Dr. Zairo Vieira, then Chairman of SBA, participated in the first Executive WFSA Committee constituted in Scheveningen. In 1964, SBA has sponsored the $3^{\text {rd }}$ World Congress of Anesthesiologists in São Paulo and by that time Dr. Luiz Fernando Rodrigues Alves was elected member of WFSA Executive Committee. Other anesthesiologists members of SBA were elected for this position in different occasions: Dr. Carlos Pereira Parsloe in 1972, Dr. José Carlos Ferraro Maia in 1980, Dr. José Roberto Nociti in 1996. In 1984, during the $7^{\text {th }}$ World Congress of Anesthesiologists held in Manila, the Philippines, Dr. Carlos Pereira Parsloe was inaugurated as Chairman of WFSA, remaining in the position until 1988.

Currently, SBA with 7319 members is the third largest member-Society of WFSA, coming after National USA and Japan Societies with 23727 and 8568 members, respectively ${ }^{1}$. One of WFSA roles has been to search for the breakeven point between major and well-structured Societies such as SBA, and minuscule Societies on the other edge, such as Zambia, Estonia and Kazakhstan with 15 members, and Papua New Guinea with 10 members.

A lot has been discussed today about Anesthesiology excellence indices, such as the number of anesthesiologists as compared to the number of people they take care of. Several factors determine this index, among them population size and economic development stage, number of physicians graduated every year and the presence of paramedical professionals practicing anesthesia.

SBA has always advocated through its WFSA representatives the idea that anesthesia is a medical procedure and, as such, should be practiced by physicians with the necessary attributes to practice it with quality and safety. Considering high North-American Anesthesiology standards, the ratio of 1 anesthesiologist per 11700 inhabitants in that country has been considered by many as reference for ideal ${ }^{3}$. Brazilian Anesthesiology is prominent in this aspect and is placed among countries with indices between the above-mentioned ideal and 1:25000, together with Japan, United Kingdom,
Italy, France, Spain, Argentina, and Uruguay ${ }^{4}$. On the other edge there are countries like Nepal (1:287000), Vietnam (1:197000), Thailand (1:124000), Guatemala (1:246000), Ecuador (1:156000) and Haiti (1:151000) $)^{3,4}$.

Brazilian Anesthesiology projection worldwide is apparent. The Brazilian Journal of Anesthesiology is one of the few bilingual publications and may be read today by physicians of English speaking countries or those adopting English as their second language. In addition, its SciELO (Scientific Electronic Library On Line) and EMBASE (Excerpta Medica Database) indexation encourages foreign colleagues to visit our national scientific production.

Organization, quality and attendance of Brazilian Congresses of Anesthesiology were recently appreciated by two members of the upper WFSA Board who have visited us: TC Kester Brown, Chairman (47 $7^{\text {th }}$ CBA, São Paulo, 2000) and Anneke Meursing, General Secretary $\left(50^{\text {th }}\right.$ CBA, Brasilia, 2003). The $13^{\text {th }}$ World Congress of Anesthesiologists, held in Paris, 2004, had 16 SBA members as official guests to participate in conferences and round tables, number never before reached in International Congresses held outside Brazil. And last but not least, Brazilian authors are seeing their scientific papers accepted for publication in several specialty journals abroad, both in Europe and North America.

A challenge is imposed to new generations not only to maintain but also to enhance this international projection of Brazilian Anesthesiology, by attending Congresses, publishing articles, participating in associative activities and occupying spaces which are legitimately ours for the quality and seriousness of our work.

\author{
José Roberto Nociti, TSA, M.D \\ Member, Executive Committee, WFSA \\ Member, Editorial Council, RBA \\ Rua Stélio Machado Loureiro, 21 \\ 14025-470 Ribeirão Preto - SP, Brazil
}

\section{REFERÊNCIAS - REFERENCES}

01. WFSA Annual Report, London, UK, July 2002.

02. WFSA Statutes and Bylaws, 2000, Art 1.02

03. Tritrakam T - Challenges in the Developing World. World Anaesthesia News, 2001;4:2-4.

04. Nociti JR - The Current Situation of Anaesthesiology in Central and South America. World Anaesthesia News, 2002;6:5. 